\title{
Immune Parameters of Dry Cows Fed Mannan Oligosaccharide and Subsequent Transfer of Immunity to Calves*
}

\author{
S. T. Franklin, ${ }^{1}$ M. C. Newman, ${ }^{1}$ K. E. Newman, ${ }^{2}$ and K. I. Meek ${ }^{1}$ \\ ${ }^{1}$ Animal Sciences Department University of Kentucky, Lexington 40546-0215 \\ ${ }^{2}$ Venture Laboratories, Inc. Lexington, Kentucky 40511
}

\begin{abstract}
The objective of this study was to evaluate the benefits of supplementation of mannan oligosaccharide (MOS) to cows during the last 3 wk of the dry period on immune function of the cows and subsequent transfer of passive immunity to their calves. Indicators of nonspecific and specific immunity were evaluated. Cows were vaccinated against rotavirus at 4 and 2 wk before expected parturition. Blood samples were obtained from cows before vaccination and at weekly intervals until calving and from calves at birth and $24 \mathrm{~h}$ for analysis of serum protein concentrations, packed cell volume, white blood cell counts, white blood cell differentials, and serum rotavirus neutralization titers. Colostrum quantity and quality were measured at calving, and immunoglobulin isotype concentrations in colostrum were determined. Specific immunity was enhanced by MOS supplementation as evidenced by greater serum rotavirus neutralization titers at calving in cows supplemented with MOS compared with control cows. Colostral rotavirus neutralization titers were not affected by treatment. Although numerical differences appeared large, there was a high degree of variability in the colostral rotavirus neutralization titers. Calves from cows fed MOS tended to have greater serum rotavirus neutralization titers compared with calves from cows fed the control diet. There was a tendency for greater increases in serum protein concentrations from birth to $24 \mathrm{~h}$ in calves from cows fed MOS compared with calves from cows fed the control diet. Results indicate that supplementation of MOS to cows during the dry period enhanced their immune response to rotavirus and tended to enhance the subsequent transfer of rotavirus antibodies to calves.
\end{abstract}

(Key words: immunity, mannan oligosaccharide, periparturient, calves)

\footnotetext{
Received February 18, 2004.

Accepted September 1, 2004.

Corresponding author: Sharon T. Franklin; e-mail: sfrankli@ uky.edu.

*This manuscript, 03-07-146, is published with the approval of the director of the Kentucky Agricultural Experiment Station.
}

\begin{abstract}
Abbreviation key: $\mathbf{M O S}=$ mannan oligosaccharide, $\mathbf{P C V}=$ packed cell volume, $\mathbf{S P C}=$ serum protein concentration, $\mathbf{W B C}=$ white blood cell.
\end{abstract}

\section{INTRODUCTION}

The periparturient period is an extremely important time for dairy cows and the offspring they are carrying. During the 3 to 4 wk before parturition, cows are not only challenged by exposure to diseases, but they also must transfer Ig from serum into colostrum to provide immunity for their calves. Unfortunately, the immune system of dairy cows becomes depressed during the periparturient period (Kehrli et al., 1989a, b), causing them to be less able to respond to challenges (Cai et al., 1994). In addition, sufficient passive transfer of immunity to the calf may be jeopardized if cows are not able to transfer enough Ig into colostrum to provide adequate colostrum quality (Stott and Fellah, 1983; Rea et al., 1996). For instance, Perino et al. (1995) reported that calves born to dams with mastitis had lower plasma protein and IgG concentrations at 10 and $24 \mathrm{~h}$ after birth compared with calves born to dams without mastitis.

Diseases such as mastitis in periparturient cows and scours in calves decrease performance and may require the use of therapeutic agents. Greater than $62 \%$ of deaths in calves are attributed to diarrhea or other digestive problems (NAHMS, 2003). Additionally, animals challenged by disease organisms have been shown to produce several classes of cytokines that can increase metabolic rate, decrease appetite, decrease milk production, and direct nutrients away from growth to mount an immune response (Williams et al., 1997; Ferket and Qureshi, 1999; Sauber et al., 1999). Often, producers administer antibiotics to help combat diseases in cows and calves. The European Union, however, recently passed legislation restricting the use of antibiotics. Alternative products are needed that may demonstrate performance, health, and economic benefits similar to those provided by antibiotics. Feed supplements that can decrease the use of antibiotics while enhancing immune function and passive transfer of immunity are needed to help dairy cows meet the challenges of the 
periparturient period and aid in survival of their offspring. Examples of dietary factors that can influence immune function range from energy and protein to micronutrients such as vitamins $\mathrm{A}$ and $\mathrm{E}$ and trace minerals (Goff and Stabel, 1990; Hogan et al., 1992; Franklin et al., 1998).

Mannan oligosaccharide (MOS) has enhanced performance, improved immune function, and inhibited colonization of the digestive tract by unfavorable microorganisms in a number of livestock species. In chickens, Ig concentrations were greater in birds receiving MOS compared with birds receiving the control diet (Savage et al., 1996). Supplementation of broiler chicks with MOS beneficially influenced the bacterial populations in the digestive system (Spring et al., 2000). Several studies (Vander Beke, 1997; Davis et al., 2002; White et al., 2002) have reported improvements in various measures of performance or immune function such as gain, feed conversion, lymphocyte transformation, and Ig concentrations, compared with unsupplemented animals. Pigs from sows supplemented with MOS performed better than pigs from unsupplemented sows, attributable in part to increased concentrations of Ig in colostrum of supplemented sows (Newman and Newman, 2001; O'Quinn et al., 2001).

The ability of MOS to alter the intestinal and fecal microflora of poultry is well documented (Spring et al., 2000; White et al., 2002). Research with cattle regarding the effects of MOS supplementation has been primarily in calves and heifers and has concentrated on alteration of the intestinal microflora. Newman and coworkers (1993) found that calves receiving MOS in milk replacer had lower coliform concentrations than unsupplemented calves. Other field data support a reduction in Salmonella concentrations in dairy heifers supplemented with MOS (K. E. Newman, personal communication, 1999), however, studies have not been conducted that evaluate the ability of MOS to influence the immune system of dairy cows and transfer of immunity to calves.

Supplementation of cows with MOS may enhance immune function of the dam and provide for improved transfer of passive immunity to the offspring. The objectives of this research, therefore, were to determine if feeding MOS to dairy cows during the close-up dry period influences immune status of the cows or the subsequent transfer of passive immunity to their calves.

\section{MATERIALS AND METHODS}

\section{Animals and Animal Procedures}

Fifty cows (30 Holstein and 20 Jersey) were randomly assigned to treatments. Immune system parameters for the dams were monitored from 4 wk before expected parturition ( $-4 \mathrm{wk}$ ) through the immediate postparturient period. Subsequently, transfer of passive immunity was monitored in the calves. All animal procedures were in accordance with the Guidelines for the Care and Use of Agricultural Animals in Agricultural Research and Teaching and were approved by the Institutional Animal Care and Use Committee.

At -4 wk, blood samples were obtained, and the cows were vaccinated against rotavirus, coronavirus, and Escherichia coli toxoid (Scourguard 3KC; Pfizer, Inc., New York, NY). Blood samples for analysis of serum protein concentrations (SPC), serum Ig concentrations, and rotavirus neutralization titers were obtained in Vacutainer tubes without anticoagulant (Becton Dickinson Vacutainer Systems, Franklin Lakes, NJ) via jugular venipuncture. Additional blood samples were obtained in Vacutainer tubes containing acid citrate dextrose for determination of packed cell volume (PCV), white blood cell (WBC) counts, and preparation of slides for WBC differentiation. At -3 wk, cows were weighed, assigned to treatments, and moved to close-up dry cow lots. Treatments were either a control diet or the control diet supplemented with MOS (10 g/animal daily of MOS; Alltech, Inc., Nicholasville, KY). The MOS was mixed into the concentrate portion of the diet, and each diet was fed as a TMR consisting of $4.1 \mathrm{~kg}$ of concentrate, $1.8 \mathrm{~kg}$ of corn silage, and $1 \mathrm{~kg}$ of alfalfa silage/ cow daily on a DM basis. An alfalfa/grass hay mixture was provided for ad libitum intake for all cows. The control diet was formulated to provide $18 \% \mathrm{CP}, 1.56$ Mcal of $\mathrm{NE}_{\mathrm{L}} / \mathrm{kg}$ of diet, $37 \% \mathrm{NDF}, 24 \% \mathrm{ADF}$, and $3.1 \%$ fat.

Cows were vaccinated a second time at $-2 \mathrm{wk}$, and blood samples were obtained weekly from $-1 \mathrm{wk}$ through parturition. At parturition, blood samples were obtained from the cows. The cows were milked in the maternity stall as soon after calving as possible. All cows received an intramuscular injection of oxytocin to facilitate complete removal of colostrum. The colostrum was weighed, the temperature was recorded, and the quality of a representative sample was estimated using a colostrometer. Colostrometer readings were corrected based on temperature (Mechor et al., 1991). Colostrum samples were frozen for later analysis of Ig concentration and rotavirus neutralization titers. Cows were weighed at the second milking after parturition.

Calves were separated from the cows before suckling, and weighed. Blood samples were collected in Vacutainer tubes without anticoagulant at birth and $24 \mathrm{~h}$ after the first feeding via jugular venipuncture for analysis of SPC, serum Ig concentrations, and rotavirus neutralization titers. Maternal colostrum was fed at the rate of $1.9 \mathrm{~L}$ for Holstein calves and 1.2 L for Jersey calves at birth and $12 \mathrm{~h}$ after the first feeding. Feeding 
of colostrum was accomplished within $3 \mathrm{~h}$ of birth except for 5 calves that were born between 2200 and $0400 \mathrm{~h}$. Time of first feeding for these calves ranged from 3.5 to $6 \mathrm{~h}$.

\section{Sample Analysis}

Serum was harvested from 10-mL Vacutainer tubes without anticoagulant for immediate determination of SPC using a handheld refractometer (Westover model RHC-200ATC, China). Samples of the serum and maternal colostrum were frozen at $-20^{\circ} \mathrm{C}$ until analysis for $\mathrm{IgG}_{1}, \mathrm{IgG}_{2}, \mathrm{IgM}$, and IgA concentrations by radial immunodiffusion (Bethyl Laboratories, Inc., Montgomery, TX). Total amounts of each Ig isotype in the colostrum were determined by multiplying the amount of colostrum obtained at the first milking by the concentration of each isotype. The total amount of Ig obtained from each cow was then determined by summing the amounts of the isotypes.

Colostrum samples obtained immediately after calving were stored frozen at $-20^{\circ} \mathrm{C}$ for determination of rotavirus neutralization titers. Serum samples from cows at wk -4 and calving and serum samples from calves at birth and $24 \mathrm{~h}$ were stored at $-20^{\circ} \mathrm{C}$ until the end of the trial. The samples were shipped frozen to the Veterinary Diagnostic Laboratory at South Dakota State University for determination of rotavirus neutralization titers (Besser et al., 1988a; Wu et al., 2001). The antibody titers were expressed as the reciprocal of the highest dilution that resulted in neutralization of the rotavirus (Archambault et al., 1988; Besser et al., 1988a; Parreño et al., 2004).

Packed cell volumes were determined using an International Clinical Centrifuge (International Equipment Co., Boston, MA). White blood cell counts were performed using a Coulter Z1 Particle Counter (Coulter Corp., Miami, FL). Blood smears were examined microscopically to determine percentages of neutrophils, eosinophils, basophils, and mononuclear leukocytes present in peripheral blood samples.

\section{Statistical Analysis}

Data from 39 (28 Holstein and 11 Jersey) multiparous cows were used to compare the effects of a control diet ( $\mathrm{n}=19 ; 14$ Holsteins and 5 Jerseys) vs. a diet supplemented with $\operatorname{MOS}(\mathrm{n}=20 ; 14$ Holsteins and 6 Jerseys) on immune parameters of cows. Fourteen Holsteins and 5 Jerseys were entering their second lactation and 14 Holsteins and 6 Jerseys were entering their third or greater lactation. Data from 41 calves, including one set each of Holstein and Jersey twins, were analyzed for effects of the control diet $(n=19)$ vs. the MOS diet
( $\mathrm{n}=22$ ) on transfer of passive immunity to calves. An additional 11 cows (2 Holsteins and 9 Jerseys) started but did not complete the project because of insufficient colostrum volume (1 Holstein and 3 Jerseys), calves that died at birth (1 Holstein and 1 Jersey), calves that nursed before sampling (4 Jerseys), or illness of the cow (1 Jersey).

Data with repeated measures were analyzed using the mixed model procedure of SAS (SAS Institute, 1996). Treatment, time, season, lactation number, and breed were included as main effects. Colostral Ig values were included as covariates for analysis of serum Ig values for calves. Colostral rotavirus neutralization titers were included as a covariate for serum titers for calves but did not significantly affect the model and were removed. Because some cows calved earlier (resulting in fewer samples) and some later than projected (resulting in excess samples), only the samples obtained before vaccination ( $-4 \mathrm{wk}), 1 \mathrm{wk}$ after the first vaccination ( $-3 \mathrm{wk})$, and at calving ( $0 \mathrm{wk}$ ) were analyzed. Rotavirus titers were analyzed both as the reciprocal of the greatest dilution that resulted in neutralization of rotavirus and as $\log$ base $_{10}$ of the reciprocals. The distributions for rotavirus neutralization titers were skewed, whereas $\log _{10}$ of the titers resulted in a more normal distribution. Results, therefore, are presented as $\log _{10}$ of the reciprocal of the titer. Effects were considered significant at $P \leq 0.05$ unless otherwise stated. Differences among least square means were determined using the predicted difference option of the mixed model procedure of SAS. Tendencies were reported at $P>0.05$ but $\leq 0.1$.

Data with single measurements or single measurements with a covariate were analyzed using the GLM procedure of SAS with treatment, lactation number, breed, and season included as main effects for cows. For calves, gender was substituted for lactation number. Corrected colostrometer readings were included as a covariate for SPC analyses. Differences were considered significant at $P \leq 0.05$. Tendencies were reported at $P$ $>0.05$ but $\leq 0.1$.

\section{RESULTS}

\section{Parameters for Dams}

There was no effect of treatment on the number of cows that did not complete the study. There were no significant breed $\times$ treatment interactions for any of the parameters measured relating to the cows. Therefore, although there were breed differences in parameters measured, both breeds responded to treatment in the same manner.

Mean SPC decreased $(P=0.001)$ from -4 wk through parturition and reached their lowest values at parturi- 
Table 1. Blood parameters of control cows and cows supplemented daily with $10 \mathrm{~g}$ of mannan oligosaccharide (MOS) per animal from 4 wk before expected parturition through parturition. ${ }^{1}$

\begin{tabular}{|c|c|c|c|c|c|c|c|c|}
\hline Item & \multicolumn{2}{|c|}{-4 wk } & \multicolumn{2}{|c|}{$-3 \mathrm{wk}$} & \multicolumn{2}{|c|}{ Parturition } & \multicolumn{2}{|c|}{$P$ value } \\
\hline & $(\mathrm{n}=19)$ & $(\mathrm{n}=20)$ & $(\mathrm{n}=19)$ & $(\mathrm{n}=20)$ & $(\mathrm{n}=19)$ & $(\mathrm{n}=20)$ & & \\
\hline Serum $\operatorname{IgG}_{1}$ & $1020 \pm 91$ & $1067 \pm 199$ & $692 \pm 99$ & $488 \pm 66$ & $332 \pm 74$ & $349 \pm 74$ & 0.001 & 0.85 \\
\hline Serum $\mathrm{IgG}_{2}, \mathrm{mg} / \mathrm{dL}$ & $1352 \pm 128$ & $1432 \pm 148$ & $1465 \pm 146$ & $1513 \pm 171$ & $1570 \pm 155$ & $1577 \pm 178$ & 0.013 & 0.88 \\
\hline Serum IgA, mg/dL & $16 \pm 1.4$ & $14 \pm 0.9$ & $12 \pm 1.4$ & $12 \pm 0.9$ & $14 \pm 2.5$ & $20 \pm 7.6$ & 0.29 & 0.46 \\
\hline Serum IgM, mg/dL & $319 \pm 34$ & $362 \pm 46$ & $330 \pm 38$ & $306 \pm 32$ & $304 \pm 44$ & $299 \pm 34$ & 0.28 & 0.22 \\
\hline Packed cell volume, \% & $39.1 \pm 1.3$ & $39.6 \pm 1.8$ & $38.0 \pm 1.4$ & $37.7 \pm 1.6$ & $42.1 \pm 1.2$ & $39.6 \pm 0.8$ & 0.03 & 0.16 \\
\hline $\mathrm{WBC},{ }^{4} 10^{6}$ cells $/ \mathrm{mL}$ & $15.8 \pm 1.1$ & $14.0 \pm 1.5$ & $13.6 \pm 1.1$ & $13.3 \pm 1.3$ & $27.0 \pm 4.7$ & $20.9 \pm 1.5$ & 0.0001 & 0.99 \\
\hline Neutrophils, $\%$ & $31.2 \pm 2.8$ & $34.9 \pm 2.0$ & $37.9 \pm 3.3$ & $37.3 \pm 2.5$ & $55.2 \pm 2.9$ & $53.5 \pm 2.6$ & 0.0001 & 0.90 \\
\hline MNL, $5 \%$ & $63.1 \pm 2.8$ & $59.4 \pm 2.5$ & $57.9 \pm 3.4$ & $57.9 \pm 2.9$ & $43.6 \pm 2.8$ & $45.2 \pm 2.6$ & 0.0001 & 0.85 \\
\hline Eosinophils, \% & $5.6 \pm 0.9$ & $5.5 \pm 1.0$ & $3.4 \pm 0.6$ & $4.3 \pm 0.9$ & $1.0 \pm 0.3$ & $1.3 \pm 0.3$ & 0.0001 & 0.71 \\
\hline
\end{tabular}

${ }^{1}$ Data are presented as means \pm SEM.

${ }^{2} \mathrm{SPC}=$ Serum protein concentration.

${ }^{3}$ Means of $\log _{10}$ of the reciprocals of the greatest dilution that provided for neutralization of rotavirus.

${ }^{4} \mathrm{WBC}=$ White blood cell counts.

${ }^{5} \mathrm{MNL}=$ Mononuclear leukocytes.

tion (Table 1). The most dramatic declines in SPC occurred within the last $2 \mathrm{wk}$ before parturition. There was no effect of treatment on SPC concentrations. Similar dramatic decreases over time $(P<0.001)$ occurred for serum $\operatorname{IgG}_{1}$, with the lowest concentrations occurring at parturition, whereas serum $\mathrm{IgG}_{2}$ concentrations gradually increased $(P=0.013)$ through parturition. Serum $\mathrm{IgG}_{1}$ concentrations at parturition were approximately $32.5 \%$ of the values measured at $-4 \mathrm{wk}$, whereas $\operatorname{IgG}_{2}$ concentrations were approximately $112 \%$ of the values at -4 wk. Both serum IgA and IgM concentrations remained constant over time. None of the serum Ig concentrations were affected by treatment $(P>0.05)$. Lactation number did not significantly affect serum $\operatorname{IgG}_{1}$ concentrations; however, there was a tendency $(P=$ $0.09)$ for a lactation number $\times$ time interaction. Secondlactation cows had a higher mean $(P=0.05)$ serum $\mathrm{IgG}_{1}$ concentration at $-3 \mathrm{wk}(739 \pm 109$ vs. $444 \pm 103)$ compared with cows with more than 2 lactations (Figure 1).

Holstein cows had greater $(P<0.01)$ serum rotavirus neutralization titers at parturition compared with Jersey cows. $\log _{10}$ of titers averaged 3.515 for Holstein cows and 3.147 for Jersey cows. Rotavirus neutralization titers increased $(P<0.001)$ from the prevaccination sample $(-4 \mathrm{wk})$ to the parturition sample (Table 1 ). Treatment affected serum rotavirus neutralization titers; with cows fed MOS having greater $(P=0.04) \log _{10}$ rotavirus neutralization titers compared with cows fed the control diet (least square means of $3.236 \pm 0.07$ and $3.013 \pm 0.08$, respectively). Although lactation number did not affect $(P=0.17)$ serum rotavirus neutralization titers of cows at parturition, there was an interaction between lactation number and treatment (Figure 2, $P=$ 0.01). Second-parity cows fed MOS had greater serum titers at parturition compared with second-parity cows fed the control diet. Serum titers of third and greater parity cows were not affected by treatment.

Packed cell volume was not affected $(P=0.16)$ by treatment but did vary $(P=0.028)$ over time (Table 1$)$. Specifically, PCV was greater $(P=0.008)$ at parturition compared with the week before parturition. White blood cell counts were not affected $(P=0.99)$ by treatment (Table 1$)$ but were greater $(P<0.001)$ at parturition compared with values at -4 and -3 wk.

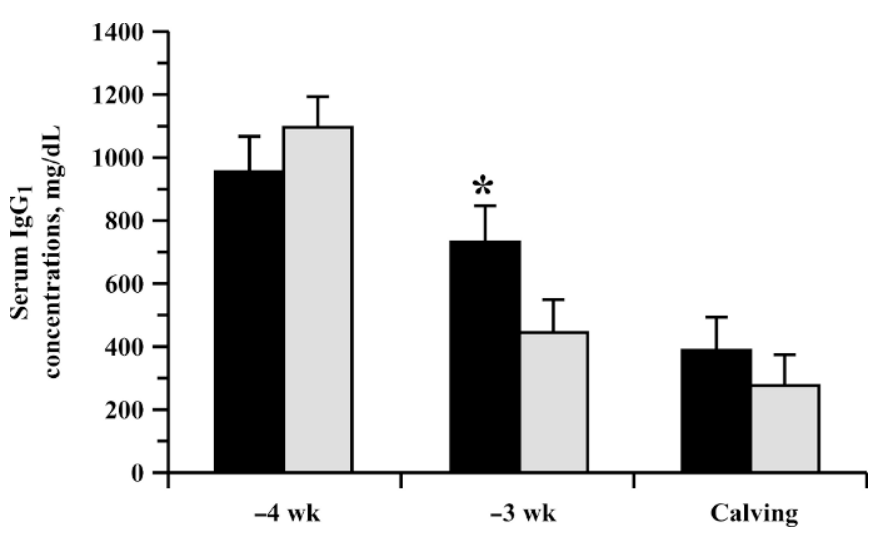

Figure 1. Concentrations of $\operatorname{IgG}_{1}$ in serum of second parity (black bars) and >second parity (gray bars) cows at 4 and 3 wk before expected parturition and at parturition. Data are presented as least square means \pm SEM. An asterisk indicates differences between parity groups at a time point at $P<0.05$. 


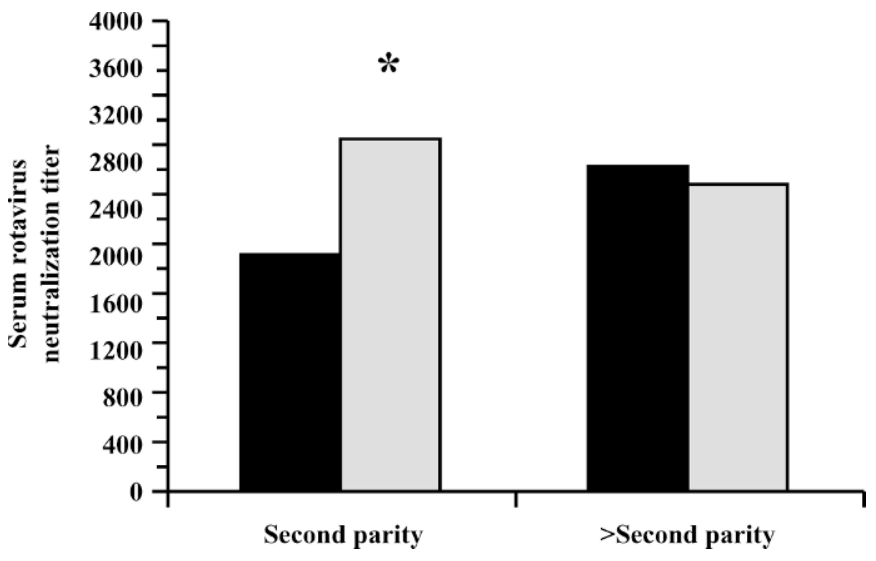

Figure 2. Serum rotavirus neutralization titers for cows fed a control diet (black bars) or a diet supplemented daily with $10 \mathrm{~g} /$ cow of mannan oligosaccharide (gray bars) and vaccinated against rotavirus at 3 and 1 wk before expected parturition. Data were analyzed as $\log _{10}$ of the reciprocal of the lowest dilution that neutralized virus. Means were converted from $\log _{10}$ back to titer reciprocals for presentation. An asterisk indicates differences within parity at $P$ $<0.05$.

Microscopic evaluation of stained blood smears indicated that the proportion of neutrophils increased $(P<$ 0.001 ) over time with greater percentages at parturition compared with -4 and -3 wk (Table 1 ). There was no effect $(P=0.90)$ of supplementation with MOS on neutrophil proportions. The proportions of mononuclear leukocytes and eosinophils decreased $(P<0.001)$ from -4 wk through parturition with no effect $(P>0.70)$ of treatment. The concentrations of the leukocyte cell types in peripheral blood were determined by multiplying the proportion of each cell type by the WBC count. Analysis of the concentrations of the leukocyte cell types indicated that the concentration of neutrophils and mononuclear leukocytes increased $(P<0.05)$ in the peripheral blood from $-4 \mathrm{wk}$ through parturition, whereas the concentration of eosinophils decreased $(P$ $<0.001$ ).

As expected, BW of cows decreased $(P<0.001)$ from 3 wk before parturition to the second milking after parturition. There was no effect $(P>0.1)$ of treatment on BW of cows. Mean BW at -3 wk was $714 \pm 143$ and 660 $\pm 129 \mathrm{~kg}$ for control and MOS treatments, respectively. At the second milking after calving, BW was $635 \pm$ 140 and $599 \pm 117 \mathrm{~kg}$ for control and MOS animals, respectively. The numerical difference between BW for the 2 treatment groups is because there were only 5 Jerseys fed the control diet compared with 6 Jerseys fed the MOS diet.

\section{Parameters for Colostrum}

When a sufficient volume of colostrum was available, calves were fed colostrum from their dam regardless of estimated colostrum quality. As expected, the amount of colostrum produced was greater $(P=0.04)$ for Holsteins $(7.87 \pm 3.97 \mathrm{~kg})$ compared with Jerseys (5.08 \pm $3.29 \mathrm{~kg})$. Neither lactation number nor supplementation with MOS affected $(P>0.05)$ the amount of colostrum produced (Table 2). Colostrometer readings corrected for temperature of the colostrum (Mechor et al., 1991) ranged from 22 to $149 \mathrm{mg} / \mathrm{mL}$ and did not differ $(P>0.05)$ by treatment (Table 2$)$. Lactation number affected specific gravity of colostrum, however, with third- and greater lactation cows having greater $(P<$ 0.001) corrected colostrometer values compared with second-lactation cows. There was no effect $(P>0.1)$ of breed on colostrometer values.

Table 2 shows concentrations of Ig in colostrum by treatment and lactation number. The $\operatorname{IgG}_{1}$ isotype was the predominant isotype in colostrum, providing approximately $90 \%$ of the Ig. There was no effect $(P=0.50)$ of treatment on colostral $\mathrm{IgG}_{1}$ concentrations. Cows in their third or greater lactation had greater colostral $\mathrm{IgG}_{1}$ concentrations compared with cows entering their second lactation, which is comparable to results for estimating colostrum quality obtained with the colostrometer.

Colostral concentrations of $\operatorname{IgG}_{2}, \operatorname{IgA}, \operatorname{IgM}$, and total Ig were not affected $(P>0.05)$ by treatment. Colostral $\mathrm{IgG}_{2}$ concentrations were affected $(P<0.05)$ by lactation number, with older cows again having greater concentrations of $\mathrm{IgG}_{2}$ compared with younger cows. Colostral rotavirus neutralization titers were not significantly affected by treatment $(P=0.21)$ or lactation number $(P=0.16)$. Although numerical differences appear large, with means of 21,777 for control compared with 26,009 for MOS, the high degree of variability in the colostral rotavirus neutralization titers prevented detection of significant differences.

\section{Parameters for Calves}

Birth weights of calves were not affected $(P>0.05)$ by treatment (Table 3 ) but were affected $(P<0.01)$ by breed (least square means of $43.6 \pm 1.4$ and $26.6 \pm 1.5$ $\mathrm{kg}$ for Holsteins and Jerseys, respectively). As expected, SPC were greater $(P<0.001)$ at $24 \mathrm{~h}$ after feeding compared with values obtained at birth. Breed did not affect $(P>0.05)$ SPC. Colostrometer readings (corrected for temperature of the colostrum) were used as a covariate for the effects of treatment on increases in SPC of calves. There was a tendency $(P=0.08)$ for a greater increase in SPC from birth to $24 \mathrm{~h}$ of age in calves from cows fed MOS compared with calves from cows fed the control diet.

Concentrations of all serum Ig isotypes increased ( $P$ $<0.001$ ) in calves from birth to $24 \mathrm{~h}$ (Table 3). Serum 
Table 2. Colostrum values for control cows and cows supplemented daily with $10 \mathrm{~g}$ of mannan oligosaccharide (MOS) per animal from 4 wk before expected parturition through parturition. ${ }^{1}$

\begin{tabular}{|c|c|c|c|c|}
\hline \multirow[b]{2}{*}{ Item } & \multicolumn{2}{|c|}{ Control } & \multicolumn{2}{|c|}{ MOS } \\
\hline & $\begin{array}{l}\text { 2nd lactation } \\
(\mathrm{n}=10)\end{array}$ & $\begin{array}{l}>2 \text { nd lactation } \\
(\mathrm{n}=9)\end{array}$ & $\begin{array}{l}\text { 2nd lactation } \\
(\mathrm{n}=9)\end{array}$ & $\begin{array}{l}>2 \text { nd lactation } \\
(\mathrm{n}=11)\end{array}$ \\
\hline Colostrum production, $\mathrm{kg}$ & $8.1 \pm 1.3$ & $6.4 \pm 1.2$ & $6.5 \pm 1.6$ & $7.1 \pm 1.1$ \\
\hline Colostrometer reading, ${ }^{2} \mathrm{mg} / \mathrm{mL}$ & $80 \pm 10^{\mathrm{b}}$ & $111 \pm 11^{\mathrm{a}}$ & $80 \pm 11^{\mathrm{b}}$ & $109 \pm 7.5^{\mathrm{a}}$ \\
\hline $\mathrm{IgG}_{1}, \mathrm{mg} / \mathrm{dL}$ & $3878 \pm 663^{\mathrm{b}}$ & $6056 \pm 1376^{\mathrm{a}}$ & $3550 \pm 710^{\mathrm{b}}$ & $5218 \pm 1082^{\mathrm{a}}$ \\
\hline $\mathrm{IgG}_{2}, \mathrm{mg} / \mathrm{dL}$ & $208 \pm 34^{\mathrm{b}}$ & $415 \pm 69^{\mathrm{a}}$ & $228 \pm 47^{\mathrm{b}}$ & $461 \pm 47^{\mathrm{a}}$ \\
\hline IgA, mg/dL & $93 \pm 26$ & $97 \pm 19$ & $140 \pm 34$ & $99 \pm 20$ \\
\hline $\mathrm{IgM}, \mathrm{mg} / \mathrm{dL}$ & $111 \pm 18$ & $88 \pm 17$ & $113 \pm 11$ & $75 \pm 12$ \\
\hline Rotavirus neutralization titer $^{3}$ & $4.30 \pm 0.10$ & $4.15 \pm 0.11$ & $4.15 \pm 0.10$ & $4.38 \pm 0.11$ \\
\hline
\end{tabular}

${ }^{\mathrm{a}, \mathrm{b}}$ Within a row, values with different superscripts differ at $P<0.05$.

${ }^{1}$ Data are presented as means \pm SEM.

${ }^{2}$ The colostrometer readings were corrected for temperature of the colostrum (Mechor et al., 1991).

${ }^{3}$ Means of $\log _{10}$ of the reciprocals of the greatest dilution that provided for neutralization of rotavirus.

$\operatorname{IgG}_{1}, \operatorname{IgG}_{2}$, and IgM concentrations were not affected $(P>0.05)$ by treatment. Serum IgA concentrations, however, were greater $(P<0.05)$ in calves from cows fed the control diet compared with calves from cows fed MOS. In contrast, serum rotavirus neutralization titers tended to be greater $(P=0.08)$ for calves from cows fed MOS compared with calves from cows fed the control diet. Only IgM concentrations were affected $(P<0.01)$ by breed, with least square means of $108 \pm 11.8$ and $174.6 \pm 18.5 \mathrm{mg} / \mathrm{mL}$ for Holsteins and Jerseys, respectively.

The PCV of calves decreased $(P=0.001)$ from birth to $24 \mathrm{~h}$, and there was no effect $(P>0.05)$ of treatment. Holstein calves had lower $(P=0.001)$ PCV compared with Jersey calves (least square means of 34.4 and
$41.7 \%$, respectively). White blood cell counts or percentages of leukocytes in whole blood of calves were not affected $(P>0.05)$ by time, treatment, or breed. There was a breed $\times$ treatment interaction for WBC counts with Jersey calves from cows fed MOS having lower WBC counts compared with Jersey calves from cows fed the control diet or Holstein calves from cows fed MOS. All values were within normal ranges, however.

\section{DISCUSSION}

The decreases observed in concentrations of serum Ig in cows before parturition, with subsequent increases in Ig concentrations in colostrum, were similar to those described by Larson (1958). Receptors for $\mathrm{IgG}_{1}$ are pres-

Table 3. Blood parameters and body weights of calves from control cows or cows supplemented with $10 \mathrm{~g}$ daily of mannan oligosaccharide (MOS) from $4 \mathrm{wk}$ before expected parturition through parturition. ${ }^{1}$

\begin{tabular}{|c|c|c|c|c|c|c|}
\hline \multirow[b]{3}{*}{ Item $^{2}$} & \multicolumn{2}{|c|}{ Birth } & \multicolumn{2}{|c|}{$24 \mathrm{~h}$} & \multirow{2}{*}{\multicolumn{2}{|c|}{$P$ values }} \\
\hline & & & & & & \\
\hline & $(\mathrm{n}=19)$ & $(\mathrm{n}=22)$ & $(\mathrm{n}=19)$ & $(\mathrm{n}=22)$ & Time & Treatment \\
\hline Birth weight, kg & $38.0 \pm 2.1$ & $35.6 \pm 2.0$ & & & & 0.23 \\
\hline $\mathrm{SPC}, \mathrm{g} / \mathrm{dL}$ & $4.2 \pm 0.07$ & $4.1 \pm 0.05$ & $5.7 \pm 0.18$ & $5.9 \pm 0.16$ & 0.0001 & 0.56 \\
\hline Increase in SPC, g/dL & 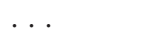 & & $1.4 \pm 0.20$ & $1.8 \pm 0.15$ & & 0.08 \\
\hline Serum $\mathrm{IgG}_{1}, \mathrm{mg} / \mathrm{dL}$ & $1.6 \pm 1.6$ & $\mathrm{ND}^{3}$ & $1490 \pm 217$ & $1786 \pm 191$ & 0.0001 & 0.31 \\
\hline Serum $\mathrm{IgG}_{2}, \mathrm{mg} / \mathrm{dL}$ & ND & ND & $124 \pm 26$ & $158 \pm 16$ & 0.0001 & 0.46 \\
\hline Serum IgA, mg/dL & ND & ND & $127 \pm 35$ & $111 \pm 21$ & 0.0001 & 0.05 \\
\hline Serum IgM, mg/dL & $13.7 \pm 5.7$ & $3.0 \pm 2.0$ & $245 \pm 34$ & $268 \pm 35$ & 0.0001 & 0.43 \\
\hline Serum titer 4 & $2.04 \pm 0.06$ & $2.10 \pm 0.07$ & $3.67 \pm 0.08$ & $3.86 \pm 0.09$ & 0.0001 & 0.08 \\
\hline $\mathrm{PCV}, \%$ & $38.9 \pm 2.1$ & $40.5 \pm 1.6$ & $36.1 \pm 1.6$ & $35.9 \pm 1.7$ & 0.001 & 0.98 \\
\hline WBC, $10^{6}$ cells $/ \mathrm{mL}$ & $14.7 \pm 1.0$ & $15.0 \pm 1.6$ & $15.2 \pm 1.5$ & $13.2 \pm 1.0$ & 0.62 & 0.19 \\
\hline Neutrophils, \% & $57.0 \pm 3.4$ & $59.4 \pm 2.7$ & $54.9 \pm 3.5$ & $56.9 \pm 2.6$ & 0.43 & 0.53 \\
\hline MNL, \% & $42.6 \pm 3.4$ & $40.3 \pm 2.7$ & $40.6 \pm 3.5$ & $42.5 \pm 2.6$ & 0.97 & 0.82 \\
\hline Eosinophils, \% & $0.3 \pm 0.1$ & $0.2 \pm 0.1$ & $0.5 \pm 0.2$ & $0.5 \pm 0.2$ & 0.13 & 0.75 \\
\hline
\end{tabular}

${ }^{1}$ Data are presented as means \pm SEM.

${ }^{2} \mathrm{SPC}=$ Serum protein concentration, $\mathrm{PCV}=$ packed cell volume, $\mathrm{WBC}=$ white blood cell count, $\mathrm{MNL}=$ mononuclear leukocytes.

${ }^{3} \mathrm{ND}=$ Not detectable.

${ }^{4}$ Means of $\log _{10}$ of the reciprocals of the greatest dilution that provided for neutralization of rotavirus. 
ent in the mammary glands of dairy cows that allow for accumulation of $\mathrm{IgG}_{1}$ at greater concentrations than present in the blood (Barrington et al., 1997), resulting in $\mathrm{IgG}_{1}$ being the predominant Ig present in colostrum. Only IgG ${ }_{1}$ decreased significantly in the serum of cows from -4 wk through parturition whereas the concentration of $\mathrm{IgG}_{2}$ increased over time. Although $\operatorname{IgG}_{1}$ was the only isotype to decrease over time, the decrease was of sufficient magnitude to cause a decrease in total serum Ig concentrations from -4 wk through parturition. The decrease in total serum Ig was mirrored by a decrease in SPC over time, indicating that SPC is of value in monitoring serum Ig concentrations in cows as well as calves.

The greater concentrations of $\mathrm{IgG}_{1}$ in colostrum of cows with more than 2 lactations compared with second-lactation cows may indicate greater expression of the $\mathrm{IgG}_{1}$ receptor in the mammary glands of older cows. This is supported by the fact that serum IgG $_{1}$ concentrations were greater at 3 wk before parturition in secondlactation cows compared with cows with more than 2 lactations. The decrease is serum $\mathrm{IgG}_{1}$ concentrations from -4 wk to parturition for second-parity cows was only $575 \mathrm{mg} / \mathrm{dL}$ compared with an 824-mg/dL decrease for cows with more than 2 parities.

Supplementation with MOS had no effect on concentrations of serum Ig isotypes; however, several factors indicated that MOS supplementation could affect immune function of cows and passive transfer of immunity to calves. None of the cows had been vaccinated against rotavirus previously; however, all cows were seropositive for rotavirus before vaccination, indicating prior natural exposure of all cows to rotavirus. After 2 vaccinations against rotavirus, serum rotavirus neutralization titers at parturition were greater for cows fed MOS compared with those from cows fed the control diet. In addition, serum rotavirus neutralization titers tended to be greater in calves from cows fed MOS compared with calves from control cows, indicating the potential for greater passive transfer of immunity against rotavirus to calves from cows fed MOS. There was also a tendency for calves from cows supplemented with MOS to have a greater increase in SPC from birth to $24 \mathrm{~h}$ compared with calves from control cows. When considered together, the rotavirus neutralization titers present in serum and colostrum of cows fed MOS, and titers in serum of their calves, indicate that daily supplementation of the dry cow diet with $10 \mathrm{~g}$ of MOS per animal has an influence on immune function.

Feeding MOS has affected immune function and health of poultry (Savage et al., 1996), swine (Newman and Newman, 2001), and neonatal calves (Newman et al., 1993). For instance, Newman and Newman (2001) reported that IgM concentrations were greater $(P=$
$0.04)$, and IgG concentrations were numerically greater $(P=0.16)$ in colostrum from sows supplemented with MOS compared with sows fed a control diet. This should lead to improved passive transfer of immunity to the pigs. Pigs from the sows supplemented with MOS had greater $(P<0.05) \mathrm{BW}$ at 7,14 , and $21 \mathrm{~d}$ compared with pigs from sows fed the control diet. Passive immune status of beef calves at $24 \mathrm{~h}$ of age is an important determinant of health and is indirectly associated with growth (Wittum and Perino, 1995). The improved concentrations of Ig in colostrum of sows fed MOS, therefore, are likely associated with the improved growth performance of the pigs.

A potential mechanism for the action of MOS may involve the presence in serum of proteins called collectins. Cattle possess 3 types of serum collectins termed conglutinin, collectin 43 , and mannose-binding protein (Srinivasan et al., 1999). Conglutinin and mannose-binding protein prefer to bind to mannose or $\mathrm{N}$ acetylglucosamine, whereas collectin- 43 prefers to bind to mannose or $N$-acetylmannosamine. Collectins may act as opsonins that may bind to mannan-containing particles, allowing for enhanced phagocytosis by the innate immune system, or they may act through activation of the complement system. Several organisms, including some viruses, have been shown to have mannans with structures similar to MOS (Epstein et al., 1996; Medzhitov and Janeway, 1997; Nielsen et al., 1999; Srinivasan et al., 1999). Nielsen et al. (1999) reported that concentrations of mannose-binding proteins increased in chickens during virus infections. It is unknown whether there are mannan components associated with rotavirus, however, if present, as they are in other viruses, mannans may be a target of the innate immune response. It may be that MOS acts as an adjuvant by stimulating the production of mannose-binding proteins (collectins) in cattle. The collectins would then be available for binding to the rotavirus after immunization, which could lead to improved phagocytosis, activation of complement, and enhancement of the immune response. Medzhitov and Janeway (1997) suggest that involvement of the innate immune system is essential for activation of the adaptive immune response. They suggest that the innate immune system provides signals that direct the adaptive immune response in the proper direction such as toward a humoral response or toward a cell-mediated response. In the present study, supplementation of MOS enhanced the humoral immune response of the dams. Enhancement of the cellmediated immune response was not investigated.

A less likely mechanism for the action of MOS involves the natural production of antimannan antibodies. Recently, researchers have reported the presence in cattle of natural antibodies (primarily of the $\operatorname{IgG}_{1}$ 
isotype) against mannan (Srinivasan et al., 1999). In particular, the study suggested that the antimannan antibodies were directed against an oligosaccharidebased epitope and that these carbohydrate-specific antibodies may be the result of a normal immune response against microflora in the gut. Supplementation of MOS to dairy cows may enhance production of these antimannan antibodies at the gut level, which in turn may enter the blood stream and allow for an enhanced response to virus vaccinations. If mannan components are present in rotavirus, the antimannan antibodies may bind to the rotavirus, resulting in opsonization of the viral particles, and allowing for improved ingestion by macrophages. The ultimate result would be enhanced production of antibodies to rotavirus by B cells.

Calves from cows supplemented with MOS had lower serum IgA concentrations compared with calves from cows not supplemented with MOS. The reason for this is unknown. Colostral concentrations of IgA did not differ between treatments, therefore the amount available to calves for absorption should have been similar. Concentrations of IgA were enhanced in colostrum of sows supplemented with MOS (O'Quinn et al., 2001), however, serum IgA concentrations in pigs were not determined. Colostral IgA is nonselectively absorbed into the bloodstream by calves whereas in pigs, IgA remains primarily in the intestinal tract (Tizard, 1996). The retention of IgA in the intestinal tract of pigs is likely related to the presence of large amounts of secretory component in the intestine compared with other species. Supplementation of cows with MOS may have altered the absorption of IgA from the intestinal tract of calves, possibly through some effect on secretory component; however, intestinal IgA was not determined in the present study. Because antibody against rotavirus is primarily of the $\operatorname{IgG}_{1}$ isotype rather than the $\operatorname{IgA}$ isotype (Besser et al., 1988a), and because IgG $_{1}$ antibodies are secreted back into the intestinal lumen of calves, the protection provided to calves through absorption of IgA is likely less important than the protection provided by IgA in other species.

Clearance of $\mathrm{IgG}_{1}$ from the bloodstream of calves occurs through transfer to the intestinal lumen, thereby providing the ability for antibody to bind to antigen in the intestinal tract (Besser et al., 1988b). Besser et al. (1988a) reported that antibody to rotavirus found in the intestinal lumen of calves fed colostrum from cows immunized against rotavirus was primarily of the $\operatorname{IgG}_{1}$ isotype and originated from the bloodstream. In contrast, IgA with antirotavirus activity was very low or undetectable in the intestine of the calves indicating that the immune system of the calf was not providing the antirotavirus activity. The authors concluded that, because of the transfer of antibody from the blood- stream of calves to the intestinal lumen, calves that were fed colostrum with greater rotavirus neutralization titers received greater protection against rotavirus in the intestine as the $\mathrm{IgG}_{1}$ was cleared from the bloodstream. The ability of MOS supplementation to enhance the rotavirus neutralization titer in serum of cows immunized against rotavirus, together with the tendency for an enhancement of rotavirus titers in the serum of their calves, provides evidence that improved intestinal protection against rotavirus in calves may be achieved because of the potential for transfer of rotavirus antibodies from the bloodstream to the intestine. Parreño et al. (2004) reported that elevated rotavirus titers in colostrum provided newborn calves with enhanced protection against rotavirus, resulting in fewer calves with symptoms and fewer days of diarrhea compared with calves fed colostrum from cows not immunized against rotavirus.

It is unknown why the younger cows supplemented with MOS had a greater response to rotavirus vaccination compared with unsupplemented cows. There was variability in the response to rotavirus vaccination among the cows. Others (Mallard et al., 1998) have reported that some cows are high responders and some are low responders. It may be that some of the older cows are more refractory because of repeated exposure to rotavirus.

The increased concentrations of WBC in cows at parturition occurred in both treatment groups. Although the decrease in the fluid portion of the blood of cows over time, as indicated by the increase in PCV, may have partially contributed to the increase in WBC counts; the mean increase in PCV was only $8 \%$, whereas the mean increase in the WBC count was $77 \%$. The increase in PCV over time may reflect decreased fluid intake just before parturition or an increase in fluid loss because of parturition. Others have noted alterations in WBC counts in the periparturient period. Kehrli et al. (1989b) reported that WBC counts peaked 2 wk before parturition; however, they did not report WBC counts at calving. Results reported here are more similar to those of Cai et al. (1994), who reported a significant effect of time for WBC counts of periparturient cows. Cai et al. (1994) reported that counts in clinically normal cows increased from $1.5 \mathrm{wk}$ before parturition until parturition, followed by a decrease in WBC counts through 4 wk postpartum.

Although the proportion of mononuclear leukocytes was lower at parturition compared with values at -4 wk, the concentration of mononuclear cells in peripheral blood was greater because of the increased concentration of WBC. The increases observed in absolute numbers of neutrophils and mononuclear leukocytes in peripheral blood of cows from -2 wk to parturition are 
similar to the increases reported by Kehrli et al. (1989b) from -6 wk to -2 wk. Kehrli et al. (1989b) did not report absolute numbers at parturition.

Mean $( \pm \mathrm{SD})$ corrected colostrometer values were 95.5 $\pm 33 \mathrm{mg} / \mathrm{mL}$, and were similar to previously reported values for multiparous Holstein cows (Franklin et al., 1998). Cows with more than 2 parities had greater colostrometer values compared with cows with 2 parities. Morin et al. (2001) reported that cows in their third or greater lactation had greater colostral specific gravity compared with cows entering their first or second lactation. Franklin et al. (1998) did not detect significant differences in corrected colostrometer readings with values of $89.2 \pm 31.5 \mathrm{mg} / \mathrm{mL}$ for Holstein cows in their third or greater lactation compared with $83.7 \pm 30.2$ $\mathrm{mg} / \mathrm{mL}$ for Holstein cows in their second lactation.

Pritchett et al. (1991) reported that the weight of colostrum obtained at the first milking was the most highly correlated variable affecting the concentration of $\mathrm{IgG}_{1}$ in colostrum and that lactation number was second. The weight of colostrum produced in the present study, however, did not differ by lactation, therefore the difference between lactation numbers regarding quality was not related to production.

In general, although differences were detected between Jerseys and Holsteins for some parameters, both breeds responded to treatment in the same manner with the exception of a breed $\times$ treatment interaction in WBC counts for calves. The WBC counts were within normal ranges, however. Further studies involving other breeds of cattle, such as beef cattle, are warranted.

\section{CONCLUSIONS}

Supplementation of MOS to dry cows resulted in enhanced response by the cows to immunization against rotavirus and a tendency for enhanced concentrations of rotavirus antibodies in serum of calves. Statistical differences in colostral rotavirus titers may not have been detected because of the high degree of variability in colostral rotavirus titers. There was a tendency for greater increases in SPC in calves from cows supplemented with MOS compared with calves from cows fed the control diet. Other nonspecific indicators of immunity were not affected by MOS supplementation in cows, colostrum, or calves. Supplementation of cows with MOS during the dry period may enhance transfer to the offspring of passive immunity against specific organisms, which may result in decreased use of therapeutic antibiotics in calves. In the case of viral pathogens, where antibiotics are not effective even though commonly administered to calves with diarrhea, the supplementation of MOS to dry cows to enhance trans- fer of passive immunity to calves may lead to decreased morbidity and medical treatments for calves.

\section{ACKNOWLEDGMENTS}

The authors express their appreciation to Alltech, Inc. (Nicholasville, KY) for financial support and supplying the MOS for this study and to the farm crew at the University of Kentucky Coldstream Dairy Farm for their assistance in feeding the cows. They also would like to thank Bernice Smith for excellent technical assistance.

\section{REFERENCES}

Archambault, D., G. Morin, Y. Elazhary, R. S. Roy, and J. H. Joncas. 1988. Immune response of pregnant heifers and cows to bovine rotavirus inoculation and passive protection to rotavirus infection in newborn calves fed colostral antibodies or colostral lymphocytes. Am. J. Vet. Res. 49:1084-1091.

Barrington, G. M., T. E. Besser, W. C. Davis, C. C. Gay, J. J. Reeves, and T. B. McFadden. 1997. Expression of immunoglobulin G1 receptors by bovine mammary epithelial cells and mammary leukocytes. J. Dairy Sci. 80:86-93.

Besser, T. E., C. C. Gay, T. C. McGuire, and J. F. Evermann. 1988a. Passive immunity to bovine rotavirus infection associated with transfer of serum antibody into the intestinal lumen. J. Virol. 62:2238-2242.

Besser, T. E., T. C. McGuire, C. C. Gay, and L. C. Pritchett. 1988b. Transfer of functional immunoglobulin G (IgG) antibody into the gastrointestinal tract accounts for IgG clearance in calves. J. Virol. 62:2234-2237.

Cai, T. Q., P. G. Weston, L. A. Lund, B. Brodie, D. J. McKenna, and W. C. Wagner. 1994. Association between neutrophil function and periparturient disorders in cows. Am. J. Vet. Res. 55:934-943.

Davis, M. E., C. V. Maxwell, D. C. Brown, B. Z. de Rodas, Z. B. Johnson, E. B. Kegley, D. H. Hellwig, and R. A. Dvorak. 2002. Effect of dietary mannan oligosaccharide and (or) pharmacological additions of copper sulfate on growth performance and immunocompetence of weanling and growing/finishing pigs. J. Anim. Sci. 80:2887-2894.

Epstein, J., Q. Eichbaum, S. Sheriff, and R. A. B. Ezekowitz. 1996. The collectins in innate immunity. Curr. Opin. Immunol. 8:29-35.

Ferket, P. R., and M. A. Qureshi. 1999. The turkey immune system and immunomodulators. Pages $17-30$ in Proc. 12th Eur. Symp. Poult. Nutr. R. P. Kwakkel and J. P. M. Bos, ed. World Poultry Sci. Assoc., Dutch Branch, Beekbergen, Holland.

Franklin, S. T., C. E. Sorenson, and D. C. Hammell. 1998. Influence of vitamin A supplementation in milk on growth, health, concentrations of vitamins in plasma, and immune parameters of calves. J. Dairy Sci. 81:2623-2632.

Goff, J. P., and J. R. Stabel. 1990. Decreased plasma retinol, $\alpha$ tocopherol and zinc concentration during the periparturient period: Effect on milk fever. J. Dairy Sci. 73:3195-3199.

Hogan, J. S., W. P. Weiss, D. A. Todhunter, K. L. Smith, and P. S. Schoenberger. 1992. Bovine neutrophil responses to parenteral vitamin E. J. Dairy Sci. 75:399-405.

Kehrli, M. E., Jr., B. J. Nonnecke, and J. A. Roth. 1989a. Alterations in bovine lymphocyte function during the periparturient period. Am. J. Vet. Res. 50:215-220.

Kehrli, M. E., Jr., B. J. Nonnecke, and J. A. Roth. 1989b. Alterations in bovine neutrophil function during the periparturient period. Am. J. Vet. Res. 50:207-214.

Larson, B. L. 1958. Transfer of specific blood serum proteins to lacteal secretions near parturition. J. Dairy Sci. 41:1033-1049.

Mallard, B. A., J. C. Dekkers, M. J. Ireland, K. E. Leslie, S. Sharif, C. Lacey Vankampen, L. Wagter, and B. N. Wilkie. 1998. Alter- 
ation in immune responsiveness during the peripartum period and its ramification on dairy cow and calf health. J. Dairy Sci. 81:585-595.

Mechor, G. D., Y. T. Gröhn, and R. J. Van Saun. 1991. Effect of temperature on colostrometer readings for estimation of immunoglobulin concentration in bovine colostrum. J. Dairy Sci. 74:3940-3943.

Medzhitov, R., and C. A. Janeway, Jr. 1997. Innate immunity: The virtues of a nonclonal system of recognition. Cell 91:295-298.

Morin, D. E., P. D. Constable, F. P. Maunsell, and G. C. McCoy. 2001. Factors associated with colostral specific gravity in dairy cows. J. Dairy Sci. 84:937-943.

NAHMS. 2003. Dairy, 2002. Part II: Changes in the United States Dairy Industry, 1991-2002. USDA:APHIS:VS,CEAH, Fort Collins, CO.

Newman, K. E., K. Jacques, and R. P. Buede. 1993. Effect of mannan oligosaccharide on performance of calves fed acidified and nonacidified milk replacer. J. Anim. Sci. 71(Suppl. 1):271.

Newman, K. E., and M. C. Newman. 2001. Evaluation of mannan oligosaccharide on the microflora and immunoglobulin status of sows and piglet performance. J. Anim. Sci. 79(Suppl. 1):189.

Nielsen, O. L., J. C. Jensenius, P. H. Jorgensen, and S. B. Laursen. 1999. Serum levels of chicken mannan-binding lectin (MBL) during virus infections; indication that chicken MBL is an acute phase reactant. Vet. Immunol. Immunopathol. 70:309-316.

O'Quinn, P. R., D. W. Funderburke, and G. W. Tibbits. 2001. Effects of dietary supplementation with mannan oligosaccharides on sow and litter performance in a commercial production system. J. Anim. Sci. 79(Suppl. 1):212.

Parreño, V., C. Bejar, A. Vagnozzi, M. Barrandeguy, V. Costantini, M. I. Craig, L. Yuan, D. Hodgins, L. Saif, and F. Fernandez. 2004. Modulation by colostrum-acquired maternal antibodies of systemic and mucosal antibody responses to rotavirus in calves experimentally challenged with bovine rotavirus. Vet. Immunol. Immunopathol. 100:7-24.

Perino, L. J., T. E. Wittum, and G. S. Ross. 1995. Effects of various risk factors on plasma protein and serum immunoglobulin concentrations of calves at postpartum hours 10 and 24. Am. J. Vet. Res. 56:1144-1148.

Pritchett, L. C., C. C. Gay, T. E. Besser, and D. D. Hancock. 1991. Management and production factors influencing immunoglobulin G1 concentration in colostrum from Holstein cows. J. Dairy Sci. 74:2336-2341.
Rea, D. E., J. W. Tyler, D. D. Hancock, T. E. Besser, L. Wilson, D. S. Krytenberg, and S. G. Sanders. 1996. Prediction of calf mortality by use of tests for passive transfer of colostral immunoglobulin. JAVMA 208:2047-2049.

SAS Institute. 1996. SAS/STAT Software: Changes and Enhancements through Release 6.11. SAS Inst., Inc., Cary, NC.

Sauber, T. E., T. S. Stahly, and B. J. Nonnecke. 1999. Effect of level of chronic immune system activation on the lactational performance of sows. J. Anim. Sci. 77:1985-1993.

Savage, T. F., P. F. Cotter, and E. I. Zakrzewska. 1996. The effect of feeding mannan oligosaccharide on immunoglobiulins, plasma IgG and bile IgA of Wrolstad MW male turkeys. Poult. Sci. 75(Suppl. 1):143.

Spring, P., C. Wenk, K. A. Dawson, and K. E. Newman. 2000. The effects of dietary mannan oligosaccharide on cecal parameters and the concentrations of enteric bacteria in the ceca of Salmonella-challenged broiler chicks. Poult. Sci. 79:205-211.

Srinivasan, A., Y. Ni, and I. Tizard. 1999. Specificity and prevalence of natural bovine antimannan antibodies. Clin. Diagn. Lab. Immunol. 6:946-952.

Stott, G. H., and A. Fellah. 1983. Colostral immunoglobulin absorption linearly related to concentration for calves. J. Dairy Sci. 66:1319-1328.

Tizard, I. R. 1996. Veterinary Immunology: An Introduction. 5th ed. W. B. Saunders Company, Philadelphia, PA.

Vander Beke, N., 1997. Het gebruik van mannanoligosacchariden (Bio-Mos) en lactobacillen (Lacto-Sacc) inbiggenvoeders. Thesis. Highschool Gent, Department Biotechnological Sciences, Landscape Management and Agriculture, Gent, Belgium.

White, L. A., M. C. Newman, G. L. Cromwell, and M. D. Lindemann. 2002. Brewers dried yeast as a source of mannan oligosaccharides for weanling pigs. J. Anim. Sci. 80:2619-2628.

Williams, N. H., T. S. Stahly, and D. R. Zimmerman. 1997. Effect of chronic immune system activation on the rate, efficiency, and composition of growth and lysine needs of pigs fed from 6 to 27 kg. J. Anim. Sci. 75:2463-2471.

Wu, W.-H., Y. Fang, R. Farwell, M. Steffen-Bien, R. R. R. Rowland, J. Christopher-Hennings, and E. A. Nelson. 2001. A 10-kDa structural protein of porcine reproductive and respiratory syndrome virus encoded by ORF2b. Virology 287:183-191.

Wittum, T. E., and L. J. Perino. 1995. Passive immune status at postpartum hour 24 and long-term health and performance of calves. Am. J. Vet. Res. 56:1149-1154. 